\title{
Analysis of life satisfaction of the elderly population on the example of Sweden, Austria and Germany
}

\author{
Rosa Zh. Kutubaeva ${ }^{1}$ \\ 1 McKinsey \& Company, Moscow, 125047, Russia
}

Received 17 August 2019 • Accepted 4 September 2019 • Published 30 September 2019

Citation: Kutubaeva RZh (2019) Analysis of life satisfaction of the elderly population on the example of Sweden, Austria and Germany. Population and Economics 3(3): 102-116. https://doi.org/10.3897/popecon.3.e47192

\begin{abstract}
Under the conditions of population ageing, particular interest is paid to the study of life satisfaction in older ages. The purpose of the article is to assess the level of life satisfaction of the population in old age. The main method is econometric modelling using individual data from the Study of Health, Ageing and Retirement in Europe (SHARE). According to the results of the study, ageing itself does not necessarily worsen one's perception of life - there is no evidence from Austria and Spain that all people systematically, regardless of the year of birth, go through a stage of a lower level of life satisfaction. An important factor of life satisfaction is health self-assessment.
\end{abstract}

\section{Keywords}

life satisfaction, health self-assessment, elderly age, ageing, cohort effect, panel data, SHARE

JEL Codes: J14, D60, I31

\section{Introduction}

Population ageing is one of the main demographic trends in developed countries. Thus, in 2017, the share of the population aged over 60 years was 25\% in Europe, in Russia - 21\%. According to UN forecasts, by 2050 the share will grow and reach $34 \%$ in Europe and 28\% in Russia (United Nations 2017).

A growing group of elderly population deserves to live with dignity in the later years of their lives (Smith 2001). Better understanding of life satisfaction in old age and the factors influencing it presents critical social interest apart from research interest.

The relevance of the topic for Russia is due to the low adaptability of the country for the elderly population: in the Global AgeWatch Index in 2015 Russia ranked 65th out of 96 countries participating in the evaluation (HelpAge 2015). The Global AgeWatch Index is 
a tool to measure the quality of life of older persons, providing an opportunity for international comparison.

In Europe, unlike Russia, the issue of population ageing became an object of study at the end of the XX century, and currently, a good information base focused on older generations has been created. To study life satisfaction of the elderly population, sociological surveys of representative groups of older ages are required, which is why this study refers to European data. The empirical base of the paper is presented by data of the Survey of Health, Ageing and Retirement in Europe (SHARE), conducted in 27 European countries between 2004 and 2016 (SHARE 2018).

The main purpose of the paper is to assess the relationship between the level of life satisfaction and ageing for the population in old age. The object of the study is satisfaction with the life of the population in older ages. The subject is determining the level of influence of age on life satisfaction of older persons in Europe (on the example of Sweden, Austria and Germany).

\section{Methodological Approaches to Life Satisfaction Assessment}

\section{Determining life satisfaction in the concept of subjective well-being}

Prior to the publication of the Guidelines on Measuring Subjective Well-being by OECD (OECD 2013) there was no consistent and universally accepted guidance on what the indicators of subjective well-being are and how to collect them for empirical research. The OECD approach to measuring subjective well-being and its component - life satisfaction - has become a synthesis of the most common approaches and has formed the basis for a uniform and universally accepted methodology of national statistical agencies and major sociological surveys.

OECD proposes a relatively broad definition of subjective well-being: a good mental state, including all the different positive and negative assessments of people of their lives, and emotional reactions of people to their experiences. Such assessments are subjective because they are tested internally, that is, they are not estimates of any external phenomenon. At the same time, they reflect well-being as it is, since the individual, through evaluation, makes it clear how nice and desirable his/her particular condition and a particular side of his/her life is.

The OECD concept of subjective well-being includes three elements:

Life evaluation in general

- Affect

- Eudaimonia (an ethical principle based on the notion that human behaviour is determined by the desire for happiness as the ultimate goal of life)

OECD provides recommendations on data collection for each element, but the object of this study is only the first element - assessment of life as a whole or satisfaction with life in general - so this paper further focuses on OECD's recommended methods of measurement and research results in literature related only to the measurement of life satisfaction.

The surveys use different formulations of the questions to evaluate life in general. However, OECD is encouraged to ask respondents one of two substitution questions.

The first is the Cantril self-anchoring working scale, used, for example, in Gallup World Poll (Bjørnskov 2010): "Please imagine a ladder with steps numbered from 0 at the bottom to 10 at the top. The top of the ladder represents the best possible life for you and the bottom of the ladder represents the worst possible life for you. If the upper step is 10 and the lower one is 0 , on which step of the ladder would you say you personally feel you stand this time? 
The second is a direct question on life satisfaction, used, for example, in the World Values Survey (Bjørnskov 2010): "Taking all things together, how satisfied are you with your life these days? Using this card, where 1 means "completely dissatisfied" and 10 means "fully satisfied", where would you place your life satisfaction as a whole?" OECD insists that both questions can reflect satisfaction with life.

Thus, this study relies on the definition of "life satisfaction" as an element of subjective well-being, which represents an evalustion of life as a whole without taking into account the emotions and eudemonism of the respondent. The measurement of this indicator is selected according to the OECD methodological recommendation: either the Cantril scale or the answer to a direct question: "How satisfied are you with life on a scale of 0 to 10 ?"

\section{Relationship between age and life satisfaction}

Many studies have found a U-shaped relationship between age and life satisfaction, in other words, young and older people are more satisfied with life than people of middle age (Frey and Stutzer 2002). There are two most popular interpretations of this form of relationship. The first is: the form of relationship reflects the impact of key events at different stages of life (marriage, birth of children and grandchildren, loss of employment, retirement, etc.), which are closely linked to the age in which they take place. The second is: the U-shape reflects the so-called cohort effect, implying that people born, for example, between 1930 and 1960 (Gwozdz and Sousa-Poza 2010). give and will always give a lower assessment of life satisfaction than other generations, thus generating a U-shaped form of connection between age and life satisfaction on the "cut" in a certain survey year.

Andrew Clark tested the hypothesis that this U-shaped form of communication is a purely cohort effect (Clark 2007). He reiterated the problem of establishing this link: cross-data do not allow to separate the effect of belonging to a particular cohort (the fact of birth in a particular year) from the effect of passing through the a certain stage in life. The way out of the situation is the use of panel data, which provide an opportunity to compare subjective well-being of representatives of the same cohort at different stages of their lives.

Using panel data of 14 waves of British household research Andrew Clark built a panel regression with fixed effects that are designed to take into account the impact of the cohort (birth in a given year), while the coefficient before the age variables in this regression should separately reflect the effect of ageing, that is, a systematic change in life satisfaction for all individuals with age regardless of the year of birth. The measure of life satisfaction and the dependent variable in the regression is the respondents' answer to the question of "To which extent are you dissatisfied or satisfied with your life as a whole?" on a scale of 1 (completely unsatisfied) to 7 (fully satisfied). Age is included in the regression as dummy variables of belonging to a certain age group.

The study concludes that the relationship between age and life satisfaction is still U-shaped, with higher levels of life satisfaction in young and old ages. However, the shape of graph is smoother than the earlier studies obtained in cross-data models, as the effect of cohort is taken into account - at the age between 20 and 55 years, satisfaction with life remains practically unchanged.

Wencke Gwozdz and Alfonso Sousa-Poza applied a similar methodology to analyze the relationship between age and life satisfaction on the data of the German Socio-Economic Panel and the Survey of Health, Ageing and Retirement in Europe (Gwozdz and Sousa-Poza 2010). Their main conclusion is: when controlling the cohort effect, life satisfaction is rela- 
tively stable throughout the life cycle for the German population. Unlike Clark's study, the sample in the Gwozdz and Sousa-Poza study was older, up to 95 years.

\section{Connecting health and life satisfaction in old age}

Literature raising the issue of satisfaction with life in old age suggests that it is changing in course of age, as "Healthy and successful ageing has its limitations" (Baltes and Smith 2003). Therefore, in all life satisfaction studies, health status - its self-assessment by the respondent or objective indicators based on medical findings - is included in the evaluation.

Based on data from the Swedish population survey, the relationship between health factors and life satisfaction in the population aged 80 and over was analysed (Berg et al. 2006). The analysis showed that objective measures, such as the presence of a diagnosed disease or indicators of limited functionality, do not have a significant effect on life satisfaction, whereas perception of one's health and psychological problems (depression) affect it.

It has also been shown that self-assessment of health and functional capacity in daily activities are the strongest explanatory factors of life satisfaction (Bowling et al. 1996).

The strong link between health self-assessment and life satisfaction is also derived from Swedish data on the population aged 65-89 with reduced self-care capacity (Borg et al. 2006).

\section{The relation of other factors to life satisfaction in old age}

Demographic factors cover the basic concepts used to describe the population (gender, age) and enable analysing with division into population groups. In addition, education, work, income and family status are also necessarily included as reference variables in the analysis of individual data of respondents.

Gender in itself may not be a significant factor in explaining the variation in life satisfaction (Wallace 2008). However, in a large number of works, separate analyses for men and women show different results. Thus, an analysis of the results of a survey of 17,000 men and women over 65 years of age showed that a high level of education is important only for men, whereas for women it is not important, but physical restrictions are (Meggiolaro and Ongaro 2013). There are studies that show that communicating with friends and acquaintances has a greater impact on women's satisfaction with life than for men (Sheung-Tak and Chan 2006). Takashi (2011) points to a closer relationship between family ties and life satisfaction for women, while men show lower levels of life satisfaction after divorce or becoming widowed.

Family status is an important determinant of life satisfaction of older persons in Europe. Research results suggest that people married or living with a partner tend to rate their wellbeing higher than single people (Buber and Engelhardt 2008).

The impact of education is ambiguous. A synthesis of 286 empirical studies of subjective well-being shows that education has little effect on it (Pinquart and Sørensen 2000).

Income positively affects the life satisfaction of older persons according to most works (Cid et al. 2007; Fernández-Ballesteros et al. 2001; Wallace 2008). However, it is worth noting that not all researchers come to the conclusion that this influence is great. At the same time, different approaches are used to estimate income: income level as a discrete value declared by the respondent; individual income named in monetary terms; household income per member; household expenditure as a proxy of its income per member. 


\section{Factor analysis of life satisfaction in old age in Sweden, Austria and Spain}

\section{Data}

The empirical part of the work is based on data from the Survey of Health, Ageing and Retirement in Europe (SHARE 2018) based on questioning the respondents. In this paper, only the waves $2,4,5$ and 6 of the study are used, as the questionnaires of only these waves contain the question of life satisfaction that are key to the work: "On a scale of 0 to 10 , where 0 means total dissatisfaction and 10 means total satisfaction, how satisfied are you with your life?" The data of each wave was processed using $\mathrm{R}$ software to combine them into a single base of the panel structure, that is, comparisons of observations over several years for the same respondent. The variables used and their description are presented in Table 1. These variables are available for each of the four waves used in the study. Descriptive variable statistics are given in the Annex in Table 6.

Table 1. Variables used in the analysis and their description.

\begin{tabular}{|c|c|c|c|}
\hline Variable & $\begin{array}{l}\text { Variable name in } \\
\text { the regression }\end{array}$ & $\begin{array}{l}\text { Units of mea- } \\
\text { surement }\end{array}$ & Description \\
\hline Life satisfaction & LS & $\begin{array}{l}\text { Discrete value } \\
\text { from } 0 \text { to } 10\end{array}$ & $\begin{array}{l}\text { "On a scale from } 0 \text { to } 10 \text {, where } 0 \text { means } \\
\text { total dissatisfaction and } 10 \text { means total sat- } \\
\text { isfaction, how satisfied are you with your } \\
\text { life?" }\end{array}$ \\
\hline Age & age & $\begin{array}{l}\text { Whole number } \\
\text { of years }\end{array}$ & $\begin{array}{l}\text { Number of years lived at the time of the in- } \\
\text { terview }\end{array}$ \\
\hline Age square & $\operatorname{age}^{\wedge} 2$ & Square Years & $\begin{array}{l}\text { Introduced to establish nonlinearity of the } \\
\text { relationship with age }\end{array}$ \\
\hline Sex & female & Fictive & $\begin{array}{l}1-\text { female } \\
0-\text { male }\end{array}$ \\
\hline Family status & $\begin{array}{l}\text { D_married } \\
\text { D_reg_part } \\
\text { D_separ } \\
\text { D_never_married } \\
\text { D_divorced } \\
\text { D_widowed }\end{array}$ & Fictive & $\begin{array}{l}\text { Family status of the respondent at the time } \\
\text { of the interview } \\
\text { - Married and living with a spouse } \\
\text { - Registered partnership } \\
\text { - Married and living separately from the } \\
\text { spouse } \\
\text { - Never married. } \\
\text { - Divorced. } \\
\text { - Widowed. }\end{array}$ \\
\hline Education & isced1997_r & $\begin{array}{l}\text { Discrete value } \\
\text { from } 0 \text { to } 6\end{array}$ & $\begin{array}{l}\text { According to the International Standard } \\
\text { Classification of Education of } 1997 \text { (UNE- } \\
\text { SCO 1997) } \\
0 \text { - Pre-school education } \\
1 \text { - Primary education } \\
2 \text { - Lower secondary education } \\
3 \text { - Upper secondary education } \\
4 \text { - Vocational education } \\
5 \text { - Higher education } \\
6 \text { - Academic Degree }\end{array}$ \\
\hline
\end{tabular}




\begin{tabular}{llll}
\hline \multicolumn{1}{c}{ Variable } & $\begin{array}{c}\text { Variable name in } \\
\text { the regression }\end{array}$ & $\begin{array}{l}\text { Units of mea- } \\
\text { surement }\end{array}$ & \multicolumn{1}{c}{ Description } \\
\hline $\begin{array}{l}\text { Logarithm } \\
\text { of household } \\
\text { income per } \\
\text { member }\end{array}$ & L_ind_inc & $\begin{array}{l}\text { Logarithm } \\
\text { of income in } \\
\text { euros }\end{array}$ & $\begin{array}{l}\text { Self-declared household income (answer to } \\
\text { the question "What was the average total } \\
\text { income of your household per month this } \\
\text { year?") in euros, divided by the number of } \\
\text { household members }\end{array}$ \\
\hline $\begin{array}{llll}\text { Number of } \\
\text { children }\end{array}$ & n_children & Integer & $\begin{array}{l}\text { Number of children stated by the respon- } \\
\text { dent }\end{array}$ \\
\hline $\begin{array}{l}\text { Number of } \\
\text { grandchildren }\end{array}$ & n_grandchildren & Integer & $\begin{array}{l}\text { Number of grandchildren stated by the } \\
\text { respondent }\end{array}$ \\
\hline $\begin{array}{l}\text { Self-assessment } \\
\text { of health }\end{array}$ & sphus & Discrete value & $\begin{array}{l}\text { "You would say that your health is..." } \\
1-\text { Excellent }\end{array}$ \\
& & from 1 to 5 & $\begin{array}{l}1-\text { Very good } \\
3-\text { Good }\end{array}$ \\
& & & $\begin{array}{l}3-\text { Not very good } \\
5-\text { Bad }\end{array}$ \\
& & &
\end{tabular}

Source: SHARE questionnaires (SHARE 2018).

\section{Comparison of average life satisfaction rates for older people in Swe- den, Austria and Spain}

An analysis of life satisfaction of older people is carried out in countries that are at different levels of development in terms of adaptability of life for older persons.

The Survey of Health, Ageing and Retirement in Europe (SHARE 2018) involves 27 countries in Europe and Israel. The selection of countries for analysis is based on the Active Ageing Index ranking of 2014 (UNECE/European Commission 2015), calculated for Europe for the first time in 2012.

The purpose of this index is to monitor active ageing at different levels: international, national and subnational. UNECE defines active ageing as follows: "The situation where old people continue to be formally employed in the labour market or participate in other unpaid productive activities (caring for family members and volunteering), live a healthy, independent and secure living." According to this definition, the index is calculated for the following directions: employment (employment rate in different older age groups); participation in society (voluntary activities, caring for children and grandchildren, caring for other adults, political participation); independent, healthy and secure living (physical activity, access to healthcare, independent living, economic security, physical security); opportunities and favourable conditions for active ageing (remaining life expectancy at age 55, share of healthy life in life expectancy at age 55, mental well-being, use of ICT, social connections, educational attainment).

In 2014, European countries ranked in descending order of the Active Ageing Index as follows (Fig. 1):

For this study, three countries of different "adaptability" to active ageing have been selected - from the top, middle and bottom of the rankings. The compulsory condition of the selection was the presence of the question on life satisfaction in the four waves $(2,4,5$, and 6$)$ of 


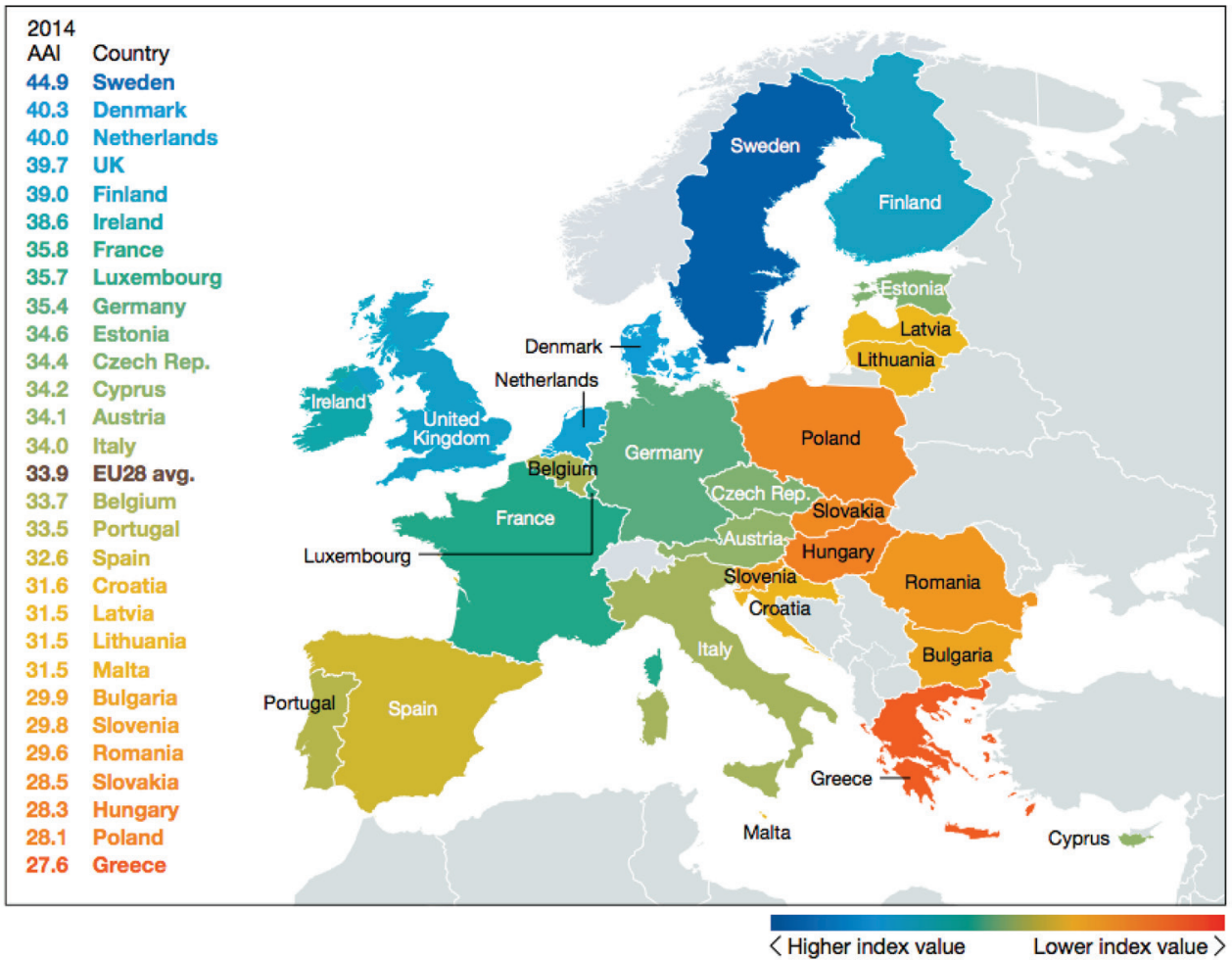

Figure 1. Ranking of 28 countries of the European Union based on the Active Ageing Index 2014. Source: Active Ageing Index 2014 Analytical Report (UNECE/European Commission 2015).

the Survey of Health, Ageing and Retirement in Europe (SHARE). Thus, Sweden, Austria and Spain are selected, where Sweden has the highest Active Ageing Index and Spain has the lowest.

It can be assumed that average life satisfaction rates for both sexes in Sweden should be higher than in Austria and Spain, and the average rate in Austria is higher than in Spain, according their location in the ranking.

Table 2 presents average life satisfaction ratings in SHARE data in the last of the available waves, number 6, conducted in all three analysed countries in 2015.

Indeed, the ratio of life satisfaction for the three countries is similar to that of the Active Aging Index, both for the sample as a whole and for each sex. It is noteworthy that the average life satisfaction in women is higher than men in each country.

Table 2. Comparison of average life satisfaction ratings by sex in Sweden, Austria and Spain in 2015. Average life satisfaction rating on a scale of 0 to 10 .

\begin{tabular}{lccc}
\hline & Total population & Women & Men \\
\hline Sweden & 8.47 & 8.48 & 8.45 \\
\hline Austria & 8.31 & 8.27 & 8.37 \\
\hline Spain & 7.88 & 7.87 & 7.91 \\
\hline
\end{tabular}

Source: calculated by the author on the basis of SHARE data, 6 th wave . 


\section{Identification of the relationship between age and life satisfaction of the elderly population}

Cross-data analysis often proves the U-shaped form of age dependency and life satisfaction over the life cycle - young and older people are more satisfied with life than middle-aged people. This form of dependence can testify two issues: either this type of connection reflects the existence of the cohort effect (the fact that people born in a given year always give and will give lower life satisfaction ratings than others), or that all people systematically, regardless of the year of birth, go through certain stages of the life cycle, characterized by a decline in satisfaction with it.

To determine whether such a U-shaped form is observed in older ages and how it is explained, three types of regressions have been constructed, reflecting the relationship between life satisfaction and age. First, cross and panel data are used to demonstrate the difference between assessing the relationship between age and life satisfaction, taking into account the cohort effect and evaluating without taking it into account. Secondly, one of the models did not include control variables, as the task is to highlight the effect of age in general, i.e. how systematically all people are affected by passing through certain stages in life where health, income, marital status, etc. change with age and therefore, indirectly affect life satisfaction through the age of the respondent. If these factors are not controlled, their effects will be separated from the effect of age.

A parametric estimation of the relationship with age is chosen, as in the study (Blanchflower and Oswald 2008), that is, age is included in the equations not as dummy variables of belonging to age groups, but as age and square of age. This is because SHARE waves were carried out with a lag of 2-4 years. Thus, splitting into 5-year age groups can significantly affect the quality of models - for many respondents, the age group will not change as the wave of the study changes.

For each of the three countries, men and women are assessed separately. Gender and country are not included as regressors because for a particular respondent for all waves gender and country remain unchanged, hence in the panel regression there will be no variation of these variables between waves, and they will not affect the estimate in any way.

Description of models:

Model 1. Ordinary linear MLS regression of Life Satisfaction Estimation by Age without Control Variables

$$
L S=\alpha+\beta_{1} * a g e+\beta_{2} * a g e^{2}+\varepsilon,
$$

where $L S$ is assessment of life satisfaction; $\beta$ - influence coefficient of age variables.

Model 2. Panel regression with fixed effects without control variables

$$
\text { LSit }=\beta_{1} * a g e_{i t}+\beta_{2} * a g e_{i t}{ }^{2}+\varepsilon_{i t}
$$

where $L S_{i t}$ is assessment of life satisfaction of the $\mathrm{i}$-th respondent in wave of study $\mathrm{t} ; \beta-$ influence coefficient of age variables.

Model 3. Fixed Effects Panel Regression with Control Variables

$$
L S_{i t}=\beta_{1} * a g e_{i t}+\beta_{2} * a g e_{i t}{ }^{2}+\Sigma \gamma_{s} * X_{i t s}+\varepsilon_{i t}
$$

where $L S_{i t}$ is assessment of life satisfaction of the $i$-th respondent in wave of study $t ; A_{i t}$ is a dummy-variable belonging to the age group of the $\mathrm{i}$-th respondent in the wave of study $t$; 
$\beta$ - influence coefficients of age variables; $X$ is the vector of control variables; $\gamma$ is the vector of coefficients before control variables.

Factors for which regression is controlled: family status, number of grandchildren and children, education, income, self-assessment of health. Specific variables are presented in the table with the results of the evaluation.

The following changes were made in the sample for each country before evaluation:

First, the sample is limited to respondents who, at the time of the interview, were at the age 50 and older to study only the elderly population. The SHARE study uses exactly 50 years of age and older as a definition of the elderly population.

Secondly, all observations for which household income per member per month was over 20,000 euros and less than 50 euros were removed. Such observations are likely to misunderstand the question of income, and they were, in one way or another, "statistical outliers" and could not provide an estimate that can be considered as applicable to a homogeneous majority of the population.

The following hypothesis is put forward: life satisfaction in old age does not depend on age. The hypothesis will be confirmed if age variables are statistically insignificant in a regression that takes into account the effect of birth in certain years.

The results of the evaluation for a sample of the Swedish population are presented below. Only variables significant at 5\% and $10 \%$ levels are interpreted. Descriptive variable statistics are given in the Annex in Table 6.

Table 3. Results of assessment of age and life satisfaction models in Sweden.

\begin{tabular}{|c|c|c|c|c|c|c|}
\hline \multirow{3}{*}{ Regressor } & \multicolumn{6}{|c|}{ Dependent variable: LS (Life Satisfaction) } \\
\hline & \multicolumn{2}{|c|}{$\begin{array}{l}\text { Model } 1 . \\
\text { Regular OLS }\end{array}$} & \multicolumn{2}{|c|}{$\begin{array}{l}\text { Model 2. Panel } \\
\text { Regression }\end{array}$} & \multicolumn{2}{|c|}{$\begin{array}{l}\text { 3. Model } 3 . \\
\text { 4. Panel regression with } \\
\text { control variables }\end{array}$} \\
\hline & Male & Female & Male & Female & Male & Female \\
\hline Const & $4,67^{* * *}$ & $4,33^{* * *}$ & 0.49 & 1.9 & 1.22 & $15,79^{* * *}$ \\
\hline Age & $0,106^{\star * *}$ & $0,11^{\star * *}$ & $0,23^{* * *}$ & $0,17^{\star *}$ & $0,19^{* *}$ & $0,16^{\star *}$ \\
\hline $\mathrm{Age}^{\wedge} 2$ & $-0,0007^{* * *}$ & $-0,0007^{* * *}$ & $-0,002^{* * *}$ & $-0,001^{* *}$ & $-0,001^{* *}$ & $-0,0009^{*}$ \\
\hline D_married & & & & & -0.04 & 0.53 \\
\hline $\begin{array}{l}\text { D_reg_prt (registered partner- } \\
\text { ship) }\end{array}$ & & & & & $1,5^{*}$ & 0.66 \\
\hline D_separ (married, separated) & & & & & 1.09 & \\
\hline D_divorced & & & & & $-0,55^{*}$ & -0.02 \\
\hline D_widowed & & & & & -0.14 & -0.3 \\
\hline n_children (number of children) & & & & & 0.03 & -0.005 \\
\hline $\begin{array}{l}\text { n_grandchildren (number of } \\
\text { grandchildren) }\end{array}$ & & & & & -0.01 & -0.006 \\
\hline isced1997_r(education) & & & & & 0.1 & $-4,1$ \\
\hline L_ind_inc (income log) & & & & & 0.08 & -0.03 \\
\hline Sphus (health self-assessment) & & & & & $-0,14^{\star * *}$ & $-0,17^{\star \star \star}$ \\
\hline $\mathrm{LSDV} \mathrm{R}^{2}$ & & & 0.73 & 0.74 & 0.74 & 0.75 \\
\hline $\mathrm{N}$ (number of observations) & 3103 & 3486 & 3103 & 3486 & 2898 & 3328 \\
\hline
\end{tabular}

D_never_married - a basic category for family status

*** significant at $1 \%,{ }^{* *}$ significant at $5 \%,{ }^{*}$ significant at $10 \%$

Source: estimated by the author on the basis of SHARE data, waves $2,4,5$, and 6 (SHARE 2018). 
Table 4. Results of assessment of age and life satisfaction models in Austria.

\begin{tabular}{|c|c|c|c|c|c|c|}
\hline \multicolumn{7}{|c|}{ Dependent variable: LS (Life Satisfaction) } \\
\hline \multirow[t]{2}{*}{ Regressor } & \multicolumn{2}{|c|}{$\begin{array}{l}\text { Model } 1 . \\
\text { Regular OLS }\end{array}$} & \multicolumn{2}{|c|}{$\begin{array}{l}\text { Model 2. Panel } \\
\text { Regression }\end{array}$} & \multicolumn{2}{|c|}{$\begin{array}{c}\text { 5. Model } 3 . \\
\text { 6. Panel regression } \\
\text { with control variables }\end{array}$} \\
\hline & Male & Female & Male & Female & Male & Female \\
\hline Const & $5.45^{\star * *}$ & $5.3^{\star * *}$ & -1.61 & $5.64^{*}$ & -1.6 & $6.48^{\star *}$ \\
\hline Age & 0.063 & $0.09^{* *}$ & $0.25^{\star *}$ & 0.04 & $0.22^{*}$ & 0.04 \\
\hline Age $^{\wedge} 2$ & -0.0003 & $-0.0006^{* *}$ & $-0.002^{*}$ & -0.0001 & -0.001 & -0.00002 \\
\hline D_married & & & & & $1.28^{* *}$ & $0.87^{\star *}$ \\
\hline D_reg_prt (registered partnership) & & & & & & -0.05 \\
\hline D_separ (married, separated) & & & & & 1.33 & -0.04 \\
\hline D_divorced & & & & & $-0.25^{\star *}$ & 0.06 \\
\hline D_widowed & & & & & 1.75 & 0.14 \\
\hline n_children (number of children) & & & & & 0.04 & -0.11 \\
\hline $\begin{array}{l}\text { n_grandchildren (number of grand- } \\
\text { children) }\end{array}$ & & & & & -0.007 & -0.02 \\
\hline isced1997_r(education) & & & & & 0.022 & -0.17 \\
\hline $\begin{array}{l}\text { L_ind_inc } \\
\text { (income } \log \text { ) }\end{array}$ & & & & & $0.11^{\star *}$ & 0.025 \\
\hline Sphus (health self-assessment) & & & & & $-0.34^{* * *}$ & $-0.29^{* * *}$ \\
\hline $\mathrm{LSDV} \mathrm{R}^{2}$ & & & 0.7 & 0.71 & 0.71 & 0.72 \\
\hline N (number of observations) & 2281 & 3660 & 2281 & 3660 & 2216 & 3581 \\
\hline
\end{tabular}

Source: estimated by the author on the basis of SHARE data, waves 2, 4, 5, and 6 (SHARE 2018).

For both sexes in Sweden, age and age square are statistically significant in all three model specifications. This indicates both the presence of the cohort effect and the actual systematic effect of ageing on life satisfaction. Moreover, even taking into account control variables, age plays a role in explaining life satisfaction, that is, ageing has an impact, all other levels of health status, income, family status and education being equal. Thus, the hypothesis of stable life satisfaction in old age for the Swedish population is not confirmed. Men closer to ages 50 or 90 are less happy than those aged 75 . This result agrees with the results (Frijters and Beatton 2012).

The results for Austria are as follows: for the male population, the cross-data did not reveal the relationship between life satisfaction and age, but with the shift to the panel structure, there were signs of positive linear relationship. However, once the control variables were included in the panel model, the link lost acceptable significance. This means that men in Austria do not have U-shaped relationship between life and age satisfaction, but there are signs of positive impact. For women, the hypothesis about the stability of life satisfaction was confirmed: on cross-data there is a relationship with age, but when moving to the panel structure, it disappeared. 
Table 5. Results of assessment of models of age and life satisfaction in Spain.

\begin{tabular}{|c|c|c|c|c|c|c|}
\hline \multicolumn{7}{|c|}{ Dependent variable: LS (Life Satisfaction) } \\
\hline \multirow[t]{2}{*}{ Regressor } & \multicolumn{2}{|c|}{$\begin{array}{c}\text { Model } 1 . \\
\text { Regular OLS }\end{array}$} & \multicolumn{2}{|c|}{$\begin{array}{l}\text { Model 2. Panel } \\
\text { Regression }\end{array}$} & \multicolumn{2}{|c|}{$\begin{array}{l}\text { 7. Model } 3 . \\
\text { 8. Panel regression } \\
\text { with control variables }\end{array}$} \\
\hline & Male & Female & Male & Female & Male & Female \\
\hline Const & $2.67^{\star}$ & $6.57^{\star * *}$ & 0.43 & 3.6 & -2.72 & 0.6 \\
\hline Age & $0.14^{* * *}$ & 0.035 & 0.19 & 0.06 & $0.28^{* *}$ & 0.16 \\
\hline Age $^{\wedge} 2$ & $-0.001^{* * *}$ & -0.0003 & -0.001 & -0.0001 & -0.002 & -0.0008 \\
\hline D_married & & & & & -0.51 & 0.38 \\
\hline D_reg_prt (registered partnership) & & & & & 0.87 & $1,76^{\star * *}$ \\
\hline D_separ (married, separated) & & & & & & -0.79 \\
\hline D_divorced & & & & & -0.67 & $-1,27^{\star * *}$ \\
\hline D_widowed & & & & & -0.09 & 0.07 \\
\hline n_children (number of children) & & & & & -0.07 & -0.11 \\
\hline n_grandchildren (number of grandchildren) & & & & & -0.06 & 0.07 \\
\hline isced1997_r(education) & & & & & $-0.18^{\star * *}$ & 0.12 \\
\hline L_ind_inc (income log) & & & & & $0.1^{*}$ & $0,12^{\star *}$ \\
\hline Sphus (health self-assessment) & & & & & $-0,37^{\star * *}$ & $-0.46^{* * *}$ \\
\hline $\mathrm{LSDV}^{2}$ & & & 0.75 & 0.7 & 0.77 & 0.73 \\
\hline $\mathrm{N}$ (number of observations) & 2698 & 3638 & 2698 & 3638 & 2437 & 3377 \\
\hline
\end{tabular}

Source: estimated by the author on the basis of SHARE data, waves 2, 4, 5, and 6 (SHARE 2018)

In the sample of the Spanish female population there is no relationship between age and life satisfaction even in the ordinary MLS model. I.e. there is no cohort effect, no pure age effect on life satisfaction. In the male population, the hypothesis about the stability of life satisfaction in old age is confirmed: in Model 1 age is statistically significant, and in Models 2 and 3 it is not significant.

So, first, in life satisfaction analysis, it is better to use a panel regression with control variables, since it separates the effect of birth in a given year from the systematic effect of ageing regardless of the year of birth. This confirms the hypothesis about the relative stability of life satisfaction. The appearance of signs of U-shaped connection between age and life satisfaction is due to the fact that people born in specific years give lower assessments of their lives than others. Second, the only stable value in all regressions of the control variable in models is self-assessment of health.

\section{Conclusion}

Due to the increase in life expectancy and the concomitant decline in fertility, there is a demographic trend of population ageing in the world. Understanding what makes life more 
comfortable for the elderly and what needs to be given to them to lead an active, full, and happy life, is of a socially significant interest.

In order to identify the impact of various factors on the satisfaction of the elderly, we have selected three countries, which take different positions in the ranking of European states by their adaptability to active and happy ageing, namely Sweden, Austria and Spain.

The first proposed research hypothesis argued that the average levels of life satisfaction in these countries correspond to their relative position in the rating of the Active Ageing Index. This hypothesis was confirmed: in general, the population of Sweden is satisfied with life more than the population of Austria and more than the population of Spain.

The second hypothesis was the assumption that life satisfaction is stable in old age, and observed decreases in average assessments at some age on cross data are caused by the effect of birth in a certain year, that is, belonging to the generation of people who evaluate and will always evaluate their lives lower than everyone else. This hypothesis was not confirmed for the Swedish population, but was confirmed for Austria and Spain. It can be concluded that ageing in itself does not necessarily worsen the perception of human life - for Austria and Spain there is no proof that all people systematically, regardless of the year of birth, go through a lower level of satisfaction with life. When assessing the relationship between age and life satisfaction, it became clear that among all the control variables, self-assessment of health by the respondent is most important.

Thus, an analysis of life satisfaction of the elderly population in Sweden, Austria and Spain showed that there was no sustainable relationship between life satisfaction and age, therefore, it cannot be said that it is a special population group experiencing an inevitable decline in life satisfaction simply because of an increase in age. State of health is particularly important for the elderly.

For future development of the research we propose to study the impact of cultural factor on the assessment of general subjective well-being, which is crucially important for cross-country comparisons. It can be realized by constructing a single panel regression on data from several countries with control on the country and age product variable.

To analyze life satisfaction specifically in old age, in the next step the impact of social relations, that is, the frequency and quality of communication with relatives, friends and acquaintances can be considered in more detail.

\section{Reference List}

Baltes MM, Smith J (2003) New frontiers in the future of ageing: From successful ageing of the young old to the dilemma of the fourth age. Gerontology 49: 123-135. https://doi. org/10.1159/000067946

Berg AI, Hassing LB, McClearn GE, Johansson B (2006) What matters for life satisfaction in the oldest-old? Ageing \& Mental Health 10(3): 257-264. https://doi.org/10.1080/13607860500409435

Bjørnskov C (2010) How Comparable are the Gallup World Poll Life Satisfaction Data? Journal of Happiness Studies 11: 41-60. https://doi.org/10.1007/s10902-008-9121-6

Blanchflower DG, Oswald AJ (2008) Is well-being U-shaped over the life cycle? Social Science \& Medicine 66(8): 1733-1749. https://doi.org/10.1016/j.socscimed.2008.01.030 
Borg C, Hallber IR, Blomquist K (2006) Life Satisfaction among the older people (65+) with reduced self-care capacity: The relationship to social, health and financial aspects. Journal of Clinical Nursing 15: 607-618. https://doi.org/10.1111/j.1365-2702.2006.01375.x

Bowling A, Farquhar M, Grundy E (1996) Associations With Changes in Life Satisasfaction among Three Samples of Elderly People Living at Home. International Journal of Geriatric Psychiatry 11/12: 1077-1087. https://doi.org/10.1002/(SICI)1099-1166(199612)11:12\%3C1077::AIDGPS466\%3E3.0.CO;2-D

Buber I, Engelhardt H (2008) Children's impact on the mental health of their older mothers and fathers: findings from the Survey of Health, Ageing and Retirement in Europe. European Journal of Ageing 5: 31-45. https://doi.org/10.1007/s10433-008-0074-8

Cid A, Ferrés D, Rossi M (2007) Testing Happiness Hypothesis among the Elderly. Documentos de Trabajo 1207. Departamento de Economía. Facultad de Ciencias Sociales. Montevideo.

Clark AE (2007) Born to be mild? Cohort effects don't (fully) explain why well-being is U-shaped in age. IZA Working Paper No.3170.

Fernández-Ballesteros R, Zamarrón M, Ruíz M (2001) The contribution of sociodemographic and psychosocial factors to life satisfaction. Ageing and Society 21: 25-43. https://doi.org/10.1017/ S0144686X01008078

Frijters P, Beatton T (2012) The mystery of the U-shaped relationship between happiness and age. Journal of Economic Behavior \& Organization 82(2-3): 525-542. https://doi.org/10.1016/j. jebo.2012.03.008

Frey BS, Stutzer A (2002) Happiness and Economics. Princeton University Press: Princeton and Oxford.

Gwozdz W, Sousa-Poza A (2010) Ageing, Health and Life Satisfaction of the Oldest Old: An Analysis for Germany. Social Indicators Research 97(3): 397-417. https://doi.org/10.1007/s11205-0099508-8

HelpAge (2015) Global AgeWatch Index 2015 Insights.

Meggiolaro S, Ongaro F (2013) Life satisfaction among older people in Italy in a gender approach. Department of Statistical Sciences. University of Padua, Working Paper Series 6. https://doi. org/10.1017/S0144686X14000956

OECD (2013) Guidelines on measuring subjective well-being http://dx.doi.org/10.1787/ 9789264191655-en

Pinquart M, Sørensen S (2000) Influences of socioeconomic status, social network, and competence on subjective well-being in later life: a meta-analysis. Psychology and Aging 15(2): 187-224. https:// doi.org/10.1037/0882-7974.15.2.187

Sheung-Tak Ch, Chan A (2006) Relationship With Others and Life Satisfaction in Later Life: Do Gender and Widowhood Make a Difference? The Journals of Gerontology: Series B 61(1): 46-53. https://doi.org/10.1093/geronb/61.1.P46

Smith J (2001) Well-being and health from age 70 to 100: Findings from the Berlin aging study. European Review 9(4): 461-477. https://doi.org/10.1017/S1062798701000424

Takashi O (2011) Gender Differences Among Elderly Japanese: Importance of family and social relations for life satisfaction. RIETI Discussion Paper Series 11-E-051. https://doi.org/10.1007/s10823012-9169-y

UNECE/European Commission (2015) Active Ageing Index 2014: Analytical Report.

United Nations (2017) United Nations Prospects.

Wallace T (2008) Life satisfaction in individuals age sixty-five years of age and older. PhD thesis, Oklahoma State University. UMI Dissertations Publishing. 
Data Source: SHARE (2018) Survey of Health, Aging and Retirement in Europe. http://www. share-project.org/

\section{Information about the author}

- Rosa Zhanybekovna Kutubaeva, business analyst (intern), McKinsey \& Company. E-mail:kutubaeva@gmail.com 


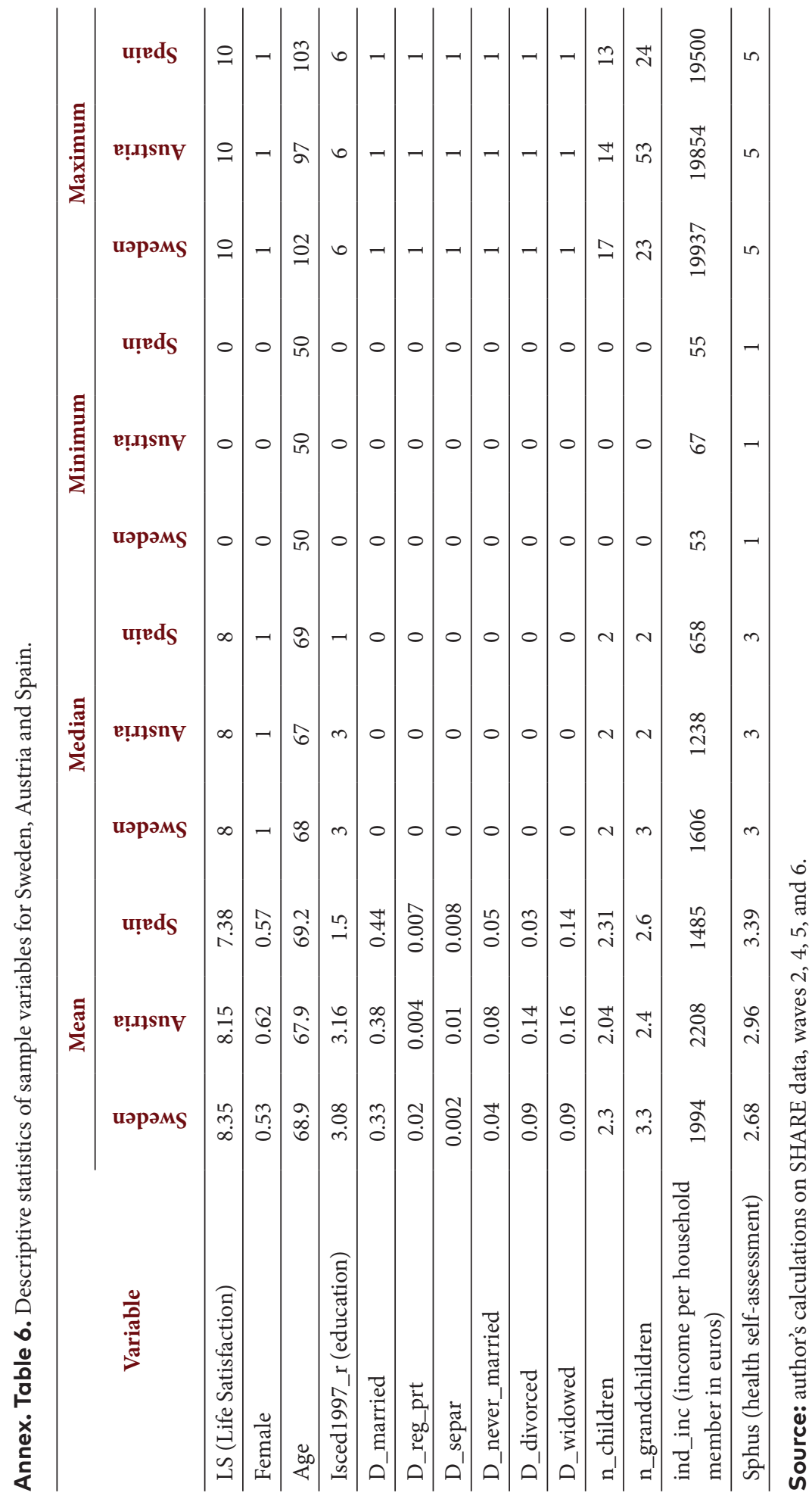

